\title{
PROBLEMATYKA RYZYKA ZAWODOWEGO W STOSUNKACH PRACY I STOSUNKACH SŁUŻBOWYCH ORAZ EGZEKWOWANIE JEGO OCENY PRZEZ PAŃSTWOWĄ INSPEKCJĘ PRACY
}

\begin{abstract}
Problems of occupational risk in labor relations and business relations and enforcement of its assessment by the National Labor Inspectorate
\end{abstract}

Risk has determination wile and there is object of interest many scientific discipline. With risk and management is tied installation definite form of activity. In working employment and installation of risk is one of guarantor of affirmation of safety unworking emploi. Regulations are included made in many sources concerning risk professional right law, who specify duties in its range of installation not only.

States are main public subject inspection of work executing executing estimate risk professional, in employment on base of relation of work suitable.

Słowa kluczowe: ryzyko, egzekwowanie, stosunek pracy i stosunek służbowy

Key words: risk, executing, relation of work and official relations

\section{Wprowadzenie}

Ryzyko w języku potocznym oznacza prawdopodobieństwo niepowodzenia lub działania, którego rezultat jest niepewny, a także działanie, które może powodować straty lub niebezpieczeństwo. Na potrzeby zarządzania organizacjami terminem „ryzyko” określa się prawdopodobieństwo wystąpienia zdarzeń, które mogą mieć istotny wpływ na realizację określonego celu.

Nie ulega wątpliwości, że cele mogą dotyczyć różnych rodzajów działalności człowieka i różnych dziedzin zarządzania. $W$ zależności od tego identyfikacji podlegają różne 
rodzaje ryzyka (np. ryzyko prowadzenia działalności gospodarczej, ryzyko finansowe, operacyjne, ryzyko zawodowe itp. $)^{1}$.

Zryzykiem i jego oceną wiąże się zarządzanie ryzykiem niezbędne w każdej działalności człowieka, które powinno obejmować identyfikację wszystkich czynników, które mogą wpływać na osiągnięcie celów i zamierzonych skutków oddziaływania tych czynników, z wykorzystaniem prawdopodobieństwa sukcesu lub porażki.

Na gruncie prawa pracy ryzyko zawodowe ponosi pracownik. Jest ono związane z oddziaływaniem czynników powodujących zagrożenia bezpieczeństwa i zdrowia mogących mieć niekorzystny wpływ na zatrudnionego i środowisko pracy, czego konsekwencją są straty materialne. Podobną sytuację obserwuje się w prawie administracyjnym regulującym stosunki służbowe, gdzie ryzyko zawodowe związane ze służbą ponosi funkcjonariusz.

Ocena ryzyka jest procesem złożonym, w którym identyfikowane są zagrożenia związane z prowadzoną działalnością. Potem następuje szacowanie - ocenianie ryzyka wynikającego z występujących zagrożeń i podejmowanie decyzji o możliwości jego zaakceptowania lub potrzebie podjęcia działań prowadzących co najmniej do jego zminimalizowania.

W procesie oceny każdego ryzyka, nie tylko pracy, należy zatem wyróżnić kilka etapów: analizę oceny ryzyka, która obejmuje identyfikację zagrożeń i oszacowanie związanego z nimi ryzyka oraz wyznaczanie jego dopuszczalności.

\section{Bezpieczeństwo i higiena pracy (służby) jako determinant ryzyka zawodowego}

Bezpieczeństwo w ogóle, $\mathrm{w}$ tym bezpieczeństwo pracy i służby, nie jest zjawiskiem trwałym, stąd też niezbędna jest troska o jego stan. Pojawiają się bowiem coraz to nowe zagrożenia związane z różnymi sytuacjami, które uzasadniają potrzebę przeciwdziałania. Rezultatów pozytywnych działań można oczekiwać natomiast wyłącznie wtedy, gdy wszystkie podmioty zobowiązane do działania zauważają i doceniają realność zagrożeń i wynikających z nich strat.

Rozwój cywilizacyjny powoduje nie tylko wiele ułatwień dla człowieka, ale również niesie ze sobą wiele zagrożeń zarówno dla jednostki, jak i zbiorowości ludzkich. Pisząc kiedyś o sytuacji we Francji, A. Peyrefitte zadał pytanie: „Milion wypadków przy pracy rocznie, z czego tysiące śmiertelnych, czy jest to nieunikniona cena postępu mechanizacji i uprzemysłowienia?"2.

Działania zmierzające do przeciwdziałania zagrożeniu bezpieczeństwa i higieny pracy czy służby powinny zatem wspierać regulacje prawne, należycie wykorzystywane $\mathrm{w}$ procesie pracy i służby przez wszystkie podmioty zobowiązane.

1 Zob. Z. Pawłowska, Ocena ryzyka zawodowego, w: Bezpieczeństwo i higiena pracy, D. Koradecka (red.), Warszawa 2008, s. 578.

2 A. Peyrefitte, Wymiar sprawiedliwości. Między ideałem a rzeczywistością, tłum. J.M. Padlewska, B. Hołysta (red.), Warszawa 1987, s. 51. 
Stopień bezpieczeństwa pracy i służby ocenia się na ogół przez pryzmat ilościowych i procentowych wskaźników wypadków podczas jej wykonywania czy wskaźników chorób związanych z pracą bądź służbą. W wielu sytuacjach liczby te na tle konkretnych wydarzeń powinny skłaniać do refleksji, czy zrobiono wszystko w celu ochrony zdrowia i życia ludzkiego, czy też można było zrobić jeszcze więcej. Podobnie bowiem jak w zatrudnieniu na podstawie stosunku pracy wypadki w czasie pełnienia służby wynikają z niewłaściwej organizacji służby, z przyczyn ludzkich (nieprzestrzegania przepisów przez wykonujących służbę) oraz z przyczyn technicznych.

Należy sobie uświadomić, że podmioty sprawujące czynności kontrolno-nadzorcze w zakresie zapewnienia bezpiecznych i higienicznych warunków pracy i służby oraz podmioty nawiązujące określone stosunki prawne są po jednej stronie oddziaływania na praworządność w zatrudnieniu, bez którego nie może się obejść integracja zatrudnionych niezbędna do realizacji zadań. Tej integracji nie sprzyjają różne uwarunkowania, jak np. niedoskonałe rozwiązania prawne, niedostateczna świadomość prawna w jej szerokim pojęciu, różnego rodzaju przyczyny natury organizacyjnej i technicznej czy też brak środków finansowych.

Ochrona zdrowia i życia zatrudnianych bez względu na podstawę świadczenia pracy czy służby jest jednym z podstawowych zadań państwa i podmiotów zatrudniających. Obowiązek zapewnienia tej ochrony wynika w szczególności z art. 5 Konstytucji RP, według którego zapewnienie szeroko rozumianego bezpieczeństwa obywatelom jest jednym z podstawowych obowiązków Rzeczypospolitej. Obowiązek ten ma charakter prawa podmiotowego chronionego prawnie w sposób kwalifikowany. Wynika to zarówno z zasady bezpośredniego stosowania Konstytucji RP (art. 8 ust. 2), jak i reguły sądowego dochodzenia naruszonych wolności i praw oraz obywatelskiego prawa do skargi konstytucyjnej (art. 79) ${ }^{3}$.

Ochrona zatrudnionych jest też często określana jako funkcja ochronna prawa pracy. Nie jest ona jednak wyłącznie domeną tego prawa. Ochrona interesów jednostki jest również przedmiotem zainteresowania m.in. prawa konstytucyjnego i administracyjnego, na co wskazują liczne regulacje zawarte w tych gałęziach prawa.

W literaturze prawa pracy brak jest jednolitego pojęcia przedmiotu ochrony pracy. Biorąc pod uwagę wartości chronione, na pierwszy plan wysuwa się ochrona zdrowia i życia zatrudnionych. Zauważa się przy tym, że obejmuje ona również i inne dobra będące przedmiotem regulacji tego prawa. Tak więc można wskazywać na wąskie i szerokie ujęcie przedmiotu ochrony ${ }^{4}$. Ochrona pracy jest też pewną metaforą. Pracy

3 E. Gdulewicz, Konstytucyjny system źródeł prawa, w: Polska lat dziewięćdziesiątych. Przemiany państwa i prawa, t. II, L. Antonowicz, H. Groszyk, M. Sawczuk, W. Skrzydło, T. Bojarski (red.), Lublin 1998, s. 50; E. Gdulewicz, Konstytucyjny system źródeł prawa, w: Polskie prawo konstytucyjne, W. Skrzydło (red.), Lublin 2011, s. 187 i n.; Z. Zakrzewski, Konstytucyjne zasady ustroju, w: Polskie prawo konstytucyjne, W. Skrzydło (red.), Lublin 2011, s. 126 i n.; W. Zakrzewski, Podstawowe prawa i obowiązki człowieka i obywatela, w: Polskie prawo konstytucyjne, W. Skrzydło (red.), Lublin 2011, s. 178, 181 i n.

4 Zob. L. Florek, Prawna ochrona pracowników. Studia i materiaty, Warszawa 1990, s. 12 i n.; W. Szubert, Szczególne właściwości prawa pracy, t. IV, Łódź 1970, s. 61; Tenże, Ochrona pracy, Warszawa 1966, 
bowiem jako takiej się nie chroni, a ochrania się interesy zatrudnionych. Ochrona pracy obejmuje więc kondycję fizyczną, intelektualno-duchową i społeczną zatrudnionego jako podmiotu ochrony. Podejście systemowe pozwala również na objęcie kategorią przedmiotu ochrony wszystkich współuczestników systemu ochrony, to jest: pracowników, podmioty nawiązujące określone stosunki prawne i państwo. System ochrony pracy, jakkolwiek jest pojęciem wieloznaczeniowym, to przyjmuje się, że jest on zharmonizowanym, wewnętrznie uporządkowanym oraz zorganizowanym układem elementów współuczestniczących o określonych powiązaniach i uwarunkowaniach ${ }^{5}$.

Wskazując np. na obowiązki w zakresie zapewnienia bezpiecznych i higienicznych warunków służby, ustawy ustrojowe dotyczące służb mundurowych odnoszą je do obowiązków w zakresie zapewnienia bezpiecznych i higienicznych warunków pracy. Nazwa "praca” występuje też w wielu ustawach normujących zatrudnienie w tych służbach i chociaż nie jest utożsamiana z pracą $\mathrm{w}$ rozumieniu art. 1 Kodeksu pracy, to jednak spełnia kryteria pracy jako takiej. Nie ma bowiem charakteru doraźnego, wykonywana jest na rzecz określonego podmiotu, pod kierownictwem, w określonym miejscu i czasie, za wynagrodzeniem oraz stanowi stałe źródło utrzymania osób zatrudnionych w tej służbie $e^{6}$. Stąd też odnoszenie przez ustawy ustrojowe dotyczące służb mundurowych warunków bezpieczeństwa i higieny pracy do służby, a nie pracy wydaje się niepotrzebnym gmatwaniem stanu mających miejsce realiów. Służba to bowiem także praca ${ }^{7}$.

Podstaw ochrony zdrowia i życia zatrudnionych w służbach mundurowych i realizacji innych uprawnień związanych z zatrudnieniem w tych służbach należy, podobnie jak i wobec pracowników, doszukiwać się także w innych unormowaniach Konstytucji RP, z których wynika szeroki zakres podmiotowy obowiązków w zakresie zapewnienia bezpiecznych i higienicznych warunków pracy ${ }^{8}$.

W zakresie zdrowia i życia zatrudnionych stanowią je w szczególności następujące przepisy Konstytucji RP:

- art. 24, według którego: „Praca znajduje się pod ochroną Rzeczypospolitej Polskiej. Państwo sprawuje nadzór nad warunkami wykonywania pracy";

- art. 38: „Rzeczypospolita Polska zapewnia każdemu prawną ochronę życia”;

s. 10; W. Jaśkiewicz, Cz. Jackowiak, W. Piotrowski, Prawo pracy w zarysie, Warszawa 1985, s. 377; T. Zieliński, Zarys wykładu prawa pracy, cz. III, Katowice 1984, s. 10-11; M. Liwo, A. Wolińska, Ochrona pracy i system jej realizacji, Miesięcznik Ochrony Pracy „Atest” 2008, 2, s. 4.

5 L. Pacholski, Założenia systemu ochrony pracy w Polsce, w: Ochrona pracy a przemiany społeczno-ekonomiczne w Polsce, R. Szpor (red.), Warszawa 1994, s. 9.

6 Zob. M. Gersdorf, Stosunek pracy, w: Kodeks pracy. Komentarz, Z. Salwa (red.), Warszawa 2008, s. 79 i n.

7 Według art. 2 pkt 43 Ustawy z dnia 20 kwietnia 2004 r. o promocji zatrudnienia i instytucjach rynku pracy (tekst jednolity Dz. U. z 2017 r., poz. 1065 ze zm.) zatrudnienie oznacza wykonywanie pracy na podstawie stosunku pracy, stosunku służbowego oraz umowy o pracę nakładczą.

8 Zob. T. Nycz, Konstytucyjne gwarancje bezpiecznych i higienicznych warunków pracy, Tarnobrzeg 2000, s. 9; zob. też M. Liwo, Ochrona pracy w Konstytucji RP z 2.04 .1997 r., w prawie międzynarodowym oraz prawie Unii Europejskiej, w: Środki ochrony praw stusznie nabytych $w$ Konstytucji RP i prawie Unii Europejskiej, H. Zięba-Załucka, P. Chmielnicki (red.), Warszawa 2012, s. 132 i n. 
- art. 66 ust. 1: „Każdy ma prawo do bezpiecznych i higienicznych warunków pracy. Sposób realizacji tego prawa oraz obowiązki pracodawcy określa ustawa”;

- art. 68 ust. 1: „Każdy ma prawo do ochrony zdrowia”.

Źródłami prawa w zakresie zapewnienia bezpiecznych i higienicznych warunków pracy i służby są również ustawy regulujące te warunki oraz oparte na upoważnieniach ustawowych rozporządzenia, a także inne akty normatywne dotyczące tej problematyki. Wiele sformułowań w dziedzinie bezpieczeństwa i higieny służby z wyraźnie wyznaczonym zakresem praw i obowiązków działania znajduje się też w różnego rodzaju postanowieniach o charakterze wewnętrznym określanych także jako specyficzne źródła prawa pracy, np. regulaminy, instrukcje i wytyczne resortowe. Koresponduje to z określeniem źródeł prawa zawartych w art. 9 Kodeksu pracy ${ }^{9}$.

Bardzo dużą liczbę regulacji prawnych zawierają utrwalone w doktrynie prawa administracyjnego i teorii prawa tzw. normy techniczne o szczególnej z punktu widzenia prawa treści i konstrukcji. Zawierają one specjalistyczne, pochodzące z różnych dziedzin nauki i techniki normatywne opisy stanów rzeczy i postępowania. Ze względu na złożoność ich treści wymagają tworzenia w strukturach administracji publicznej wyspecjalizowanych jednostek organizacyjnych, które zajmują się wykonywaniem zawartych w nich przepisów oraz kontrolą spełnienia określonych w nich wymagań. Jednostkami tymi są np. różnego rodzaju inspekcje specjalne, dozory i nadzory ${ }^{10}$.

W literaturze prawa pracy nazewnictwo „normy techniczne” występuje natomiast wobec Polskich Norm, które są wydawane na podstawie Ustawy z dnia 12 września 2002 r. o normalizacji ${ }^{11}$. Normy te, nie będąc przepisami bezpieczeństwa i higieny pracy, zawierają w swojej treści wzorce postępowania zapewniające to bezpieczeństwo przez wskazanie określonych rozwiązań z dziedziny techniczno-organizacyjnej ${ }^{12}$. Jakkolwiek stosowanie Polskich Norm jest dobrowolne, to mogą być one powoływane w przepisach prawnych po ich opublikowaniu w języku polskim.

Omawiając źródła prawa w zakresie bezpieczeństwa i higieny pracy, należy także zwrócić uwagę na zasady bezpieczeństwa i higieny pracy, tj. reguły postępowania wynikające z postępu naukowo-technicznego, doświadczenia życiowego itp., które nie mając charakteru norm prawych, wskazują na sposób wykonywania określonych czynności w procesie pracy w bezpieczny sposób. O nazwaniu określonej reguły zasadą prawa pracy, w tym bezpieczeństwa i higieny pracy, decyduje przede wszystkim jej

9 Chociaż w Konstytucji RP brak jest odesłania do regulaminów, statutów, wytycznych jako źródeł prawa, nie uniemożliwia to jednak ich uznania za źródła prawa w służbach mundurowych, podobnie jak to ma miejsce wobec stosunków pracy; zob. J. Skoczyński, Regulaminy pracy, w: Źródła prawa pracy, L. Florek (red.), Warszawa 2000, s. 153 i n. Źródłami obowiązków w omawianym zakresie mogą być również statuty, zob. A. Jedliński, L. Kaczyński, Statut jako źródło prawa pracy, Państwowa Inspekcja Pracy 1999, 4, s. 28 i n.

10 Zob.Z. Cieślak, Normy techniczne, w: Prawo administracyjne, Z. Niewiadomski (red.), Warszawa 2007, s. 79.

11 Tekst jednolity Dz. U. z 2015 r., poz. 1483.

12 E. Modliński, Bezpieczeństwo i higiena pracy, Warszawa 1975, s. 12. 
powszechny zakres obowiązywania ${ }^{13}$. Przepisy Kodeksu pracy zawarte m.in. w art. $207 \$ 2$ pkt 2 zobowiązują do przestrzegania tych zasad. Czynią to także inne regulacje prawne, $w$ tym dotyczące przestrzegania bezpieczeństwa i higieny pracy w poszczególnych służbach, które to przepisy warunkują zapewnienie bezpiecznych i higienicznych warunków służby. Poszanowanie określonych zasad bezpieczeństwa pracy w procesie służby jest również niezbędne.

Przepisy regulujące funkcjonowanie służb mundurowych i obowiązków w zakresie zapewnienia bezpiecznych i higienicznych warunków służby zawierają w swojej treści wiele odesłań do przepisów bezpieczeństwa i higieny pracy zawartych w Kodeksie pracy oraz przepisów wykonawczych do tego kodeksu stanowiących obszerny dział ustawodawstwa pracy. Jest to bowiem dziedzina, w której prawo pracy w dużym zakresie wkracza w problematykę organizacyjną i techniczną procesu zatrudnienia, ze względu na dobro chronione przez ten dział prawa, którym jest życie i zdrowie zatrudnionego. Odesłanie to jest $\mathrm{w}$ pełni uzasadnione. Korzystanie $\mathrm{z}$ dorobku prawa pracy w tym przedmiocie przez prawo administracyjne nie niweczy też tożsamości tego prawa i specyficznego charakteru zatrudnienia w służbach mundurowych na podstawie stosunku administracyjnoprawnego. Także odwrotnie, ustawodawstwo pracy korzysta z materii będącej przedmiotem regulacji prawa administracyjnego, wzbogacając możliwości oddziaływania prawa pracy na praworządność w stosunkach pracy. Przykładem tego może być instytucja nadzoru i kontroli sprawowana przez wyspecjalizowane ograny administracji rządowej wykonujące ten nadzór, bez którego trudno byłoby wyobrazić sobie egzekwowanie praw i obowiązków zatrudnionych od podmiotów zatrudniających, czy też Państwową Inspekcję Pracy usytuowaną poza administracją rządową ${ }^{14}$.

Ustawodawca nie zdefiniował dotąd zarówno przepisów bezpieczeństwa i higieny pracy, jak i bezpiecznych i higienicznych warunków pracy. W art. $9 \$ 1$ Kodeksu pracy zawarł natomiast kodeksową definicję prawa pracy, rozumiejąc pod tym pojęciem przepisy Kodeksu pracy oraz przepisy innych ustaw i aktów wykonawczych określające prawa i obowiązki pracowników i pracodawców, a także postanowienia układów zbiorowych pracy i innych opartych na ustawie porozumień zbiorowych, regulaminów i statutów określających prawa i obowiązki stron stosunku pracy. Jakkolwiek też przepisy bhp są częścią prawa pracy i jako takie w dużej mierze usytuowane są w Kodeksie pracy ${ }^{15}$, to nie w pełni racjonalny jest pogląd, że stanowią one wyłącznie domenę prawa pracy, duża ich część znajduje się bowiem poza tym prawem. Zaliczanie przepisów bhp w całości do przepisów prawa pracy stanowiłoby zatem poświęcenie prawdy na rzecz wygody doktrynalnej ${ }^{16}$.

13 R. Celeda, Zasady bezpieczeństwa i higieny pracy, Informator Ochrony Pracy 2009, 1, s. 15.

14 Zob. T. Zieliński, Stosunek prawa administracyjnego do prawa pracy, Warszawa 1977, s. 47 i n.

15 W. Szubert, Uwagi o pojęciu ochrony pracy, w: Rozprawy prawnicze. Ksiega pamiątkowa dla uczczenia pracy naukowej K. Przybyłowskiego, praca zbiorowa, Kraków-Warszawa 1964, s. 388.

16 Zob. M. Flasiński, Bezpieczeństwo pracy. Prawne formy zapobiegania zagrożeniom, Warszawa 1989, s. 21-26. Zob. też W. Muszalski, Prawo bezpieczeństwa i higieny pracy oraz jego stanowienie, w: Z problematyki prawa pracy i polityki socjalnej, T. Zieliński (red.), t. II, Katowice 1979, s. 25. 
Jak przyjmuje się w literaturze prawa pracy, do przepisów tego prawa zalicza się też m.in. problematykę zatrudniania i pośrednictwo pracy czy regulacje dotyczące funkcjonowania inspekcji specjalnych ( $\mathrm{w}$ tym Państwową Inspekcję Pracy) ${ }^{17}$. Z tym poglądem nie należy się jednak zgodzić, ponieważ regulacje te zawarte zostały w odrębnych ustawach nienależących $\mathrm{w}$ żadnym razie do prawa pracy oraz nie zostały wydane na podstawie i w trybie wykonania do ustaw należących do źródeł prawa pracy w myśl art. 9 Kodeksu pracy. Można im jednak przypisać związek z prawem pracy.

To zatem doktrynalne rozszerzenie pojęcia prawa pracy o regulacje prawne, które ze względu na ich przedmiot i formy działania organów stanowią prawne formy działania właściwe organom administracji, nie jest uzasadnione. Okoliczność zaś, że w określonym zakresie organy te zajmują się problematyką zatrudnienia czy prawa pracy, jest przejawem co najwyżej wzajemnego przenikania się tych dwóch gałęzi prawa, tj. prawa administracyjnego i prawa pracy, co jednak nie powoduje zatarcia tożsamości tych różnych gałęzi ${ }^{18}$.

Jakkolwiek mając na uwadze przepisy bhp, wymienia się między innymi art. 66 ust. 1 Konstytucji RP, art. 55 Kodeksu pracy, dział X Kodeksu pracy oraz przepisy wykonawcze kodeksowe i pozakodeksowe, ustawy szczególne w rozumieniu art. 9 Kodeksu pracy zawierające postanowienia w zakresie bhp oraz przepisy wykonawcze do tych ustaw, a także inne ustawy i postanowienia $\mathrm{z}$ dziedziny bhp, to pojawiają się różne poglądy w przedmiocie rozumienia przepisów bhp. Jeden z nich np. przyjmuje, że wszystkie przepisy aktu prawnego, który ma w tytule „bezpieczeństwo i higiena pracy”, są przepisami bhp, a drugi zawęża to pojęcie do przepisów, które regulują rzeczywiste problemy bezpieczeństwa i higieny pracy. Według np. stanowiska Stowarzyszenia Ochrony Pracy w Polsce w sprawie pojęcia przepisów bhp w prawie pracy odwołującego się do art. 207 Kodeksu pracy, podstawowego dla działu X tego kodeksu, przepisami bhp są wyłącznie przepisy, które dotyczą warunków środowiska pracy i mają na celu ochronę zdrowia i życia pracowników.

17 T.M. Nycz, Kodeks pracy z komentarzem, Kraków-Tarnobrzeg 2008, s. 25-26; L. Florek, T. Zieliński, Prawo pracy a polityka społeczno-gospodarcza i postęp społeczny, w: Z problematyki prawa pracy i polityki socjalnej, T. Zieliński (red.), t. I, Katowice 1977, s. 5. Według nich jedną z grup stosunków, które zalicza się do przedmiotu prawa pracy, są stosunki organizacyjne związane z prowadzeniem przez państwo i inne podmioty polityki zatrudniania. Grupa ta obejmuje stosunki, w jakich z organami pośrednictwa pracy (urzędami pracy) pozostają osoby poszukujące pracy. Łącznie z działalnością organów nadzoru nad warunkami pracy (inspekcja pracy) nosi ona miano „administracji pracy”. Tak również E. Ura, Prawo administracyjne, Warszawa 2008, s. 541.

18 Z. Leoński zalicza np. do policji administracyjnej, której funkcje pełnią nie tylko umundurowane i uzbrojone na wzór wojska formacje, także i inne organy administracji zapewniające bezpieczeństwo publiczne, które usuwają zagrożenia dla życia, porządku publicznego itp. Wskazuje on przy tym na takie organy, jak m.in. Nadzór budowlany, Państwowa Inspekcja Sanitarna. Zdaniem autora w wyliczeniu tym mieści się także Państwowa Inspekcja Pracy podległa Sejmowi, odpowiedzialna za bezpieczeństwo w środowisku pracy, którego niezapewnienie może powodować również zagrożenie innych rodzajów bezpieczeństwa. Zob. Z. Leoński, Działania administracji publicznej w stanach zagrożenia - policja administracyjna, w: Materialne prawo administracyjne, Z. Leoński (red.), Warszawa 2006, s. 206 i n. 
W tak też rozumianych przepisach bhp, zdaniem tego stowarzyszenia, nie mieszczą się wszystkie przepisy zawarte w dziale X Kodeksu pracy ${ }^{19}$. Nie wszystkie bowiem zmierzają bezpośrednio do ochrony zdrowia i życia pracownika w procesie pracy, bo nie określają wymagań, jakim powinny odpowiadać te warunki, tj. środowisko, w którym odbywa się świadczenie pracy ${ }^{20}$.

Na tle tych rozbieżnych stanowisk zasadny jest pogląd, że jakkolwiek wszystkie przepisy zawarte w dziale X Kodeksu pracy zatytułowanym „Bezpieczeństwo i higiena pracy” są przepisami związanymi z bhp, bo taka jest wola ustawodawcy, to jednak nie ulega wątpliwości, że nie wszystkie ze względu na zawarte w nich treści określają wymagania, jakim powinny odpowiadać warunki środowiska pracy. Stąd też różny jest charakter tych przepisów (często informacyjno-instruktażowy), który nie spełnia przesłanek np. do wydawania na ich podstawie decyzji administracyjnych.

Wśród wielu definicji dotyczących bhp należy wskazać na definicję określającą bezpieczeństwo i higienę pracy jako ogół środków i urządzeń służących do zapewnienia warunków pracy eliminujących zagrożenia życia i zdrowia zatrudnionych przez usuwanie lub ograniczanie szkodliwości związanych z procesem pracy i ze środowiskiem pracy. Do szkodliwości tych należą: zagrożenia ze strony maszyn i urządzeń technicznych, szkodliwe gazy, pary, promieniowanie, temperatura za wysoka lub za niska, hałas, wstrząsy itp. Bezpieczeństwo i higiena pracy wiążą się więc z zapobieganiem wypadkom przy pracy, chorobom zawodowym i innym szkodliwym wpływom pracy na zdrowie. Do środków służących zapewnieniu bezpiecznej pracy należy odpowiednie zaplanowanie i urządzenie pomieszczeń pracy, udoskonalania procesów wytwórczych, zapewnianie bezpieczeństwa technicznego (np. osłon przy maszynach), stosowanie odzieży ochronnej i sprzętu ochrony indywidualnej, szkolenie w zakresie bezpiecznych metod pracy ${ }^{21}$.

Zdrowie to natomiast stan żywego organizmu, w którym wszystkie funkcje przebiegają prawidłowo, a higiena to dział medyczny - nauka zajmująca się wpływem środowiska na zdrowie człowieka, dążąca do eliminacji czynników ujemnych w procesie pracy i to bez względu na podstawę świadczenia pracy.

Bezpieczeństwo i higiena pracy mają również swój odpowiednik w języku angielskim Occupational Health and Safety. Wskazuje to na międzynarodowe znaczenie tego pojęcia. Z przytoczonych wyżej pojęć wynika, że bezpieczeństwo i higiena pracy realizowane są przez działania zmierzające do zapewnienia ochrony zdrowia i życia zatrudnionych $\mathrm{w}$ procesie pracy.

W tym kontekście pojawia się także wiele innych określeń bezpieczeństwa jako takiego. Wśród nich należy wskazać na określenia, według których bezpieczeństwo to stan:

19 Zob. szerzej Stanowisko Stowarzyszenia Ochrony Pracy w sprawie pojęcia przepisów bhp w prawie pracy, Informator Ochrony Pracy 2010, VII-IX, s. 3.

20 Tamże, s. 4.

21 K.R. Szymański, T. Majdan, Leksykon ochrony pracy, Warszawa 2007, s. 26 (tytuł oryginalny: Taschen Lexikon Arbeit und Gasundheit Wiesbaden). 
- w którym zagrożenia utrzymane są pod kontrolą;

- zgodny z regulacjami prawnymi, których celem jest zapewnienie bezpieczeństwa;

- w którym ryzyko jest na poziomie akceptowalnym.

Problematyka bezpieczeństwa i higieny pracy jest też przedmiotem regulacji międzynarodowych, w tym Międzynarodowego Paktu Praw Społecznych, Gospodarczych i Kulturalnych z 19 grudnia 1966 r. ${ }^{22}$ Pakt ten w art. 7 uznaje prawo każdego do korzystania ze sprawiedliwych warunków pracy obejmujących w szczególności warunki pracy odpowiadające wymaganiom bezpieczeństwa i higieny pracy.

Aktywna w dziedzinie bezpieczeństwa i higieny pracy jest też Międzynarodowa Organizacja Pracy, która uchwaliła ponad 180 konwencji od 1919 r., z których 88 zostało ratyfikowanych przez Polskę ${ }^{23}$.

Ochronie zdrowia i bezpieczeństwa pracowników poświęcony jest również art. 118a Traktatu Rzymskiego i art. 137 Traktatu Amsterdamskiego, w którym posłużono się pojęciem „ochrona zdrowia i bezpieczeństwa pracowników” w miejsce wcześniejszego określenia „bezpieczeństwo i higiena pracy” ${ }^{24}$. Problematyka ochrony zdrowia i bezpieczeństwa pracowników była także przedmiotem art. 3 Europejskiej Karty Społecznej przyjętej w Turynie w $1961 \mathrm{r}$.

Jakkolwiek z powołanych aktów prawnych wynikają określone ograniczenia w zakresie ich stosowania w administracji publicznej i służbach mundurowych (w których zatrudnienie ma charakter specyficzny i wiąże się ze wzmożonym ryzykiem narażenia na niebezpieczeństwo), to w myśl art. 5 Konstytucji RP traktującego o obowiązku Rzeczypospolitej Polskiej w zakresie zapewnienia m.in. szeroko pojętego bezpieczeństwa obywateli i art. 66 Konstytucji RP o prawie każdego do bezpiecznych i higienicznych warunków pracy oraz ochronie pracy przez Rzeczpospolitą Polską, trudno byłoby pogodzić się ze zwolnieniem państwa $z$ działań zapewniających to bezpieczeństwo wszędzie tam, gdzie jest to możliwe z uwzględnieniem specyficznych warunków zatrudnienia, w tym również w służbach mundurowych, przy co najmniej odpowiednim wykorzystaniu postępu naukowo-technicznego. Uzasadnia to ranga ustawy zasadniczej w systemie źródła prawa oraz fakt, że regulacje międzynarodowe ustanawiają wymogi minimalne. Należy także zauważyć, że wzmożone ryzyko narażania na niebezpieczeństwo występuje również w wielu czynnościach wykonywanych na podstawie stosunku pracy. Wymagają one bezwzględnego przestrzegania przepisów, które dotyczą określonego rodzaju pracy, np. przy wytwarzaniu i stosowaniu określonych preparatów, pracy na wysokości, w zagłębieniach i otworach.

Integracja Polski z Unią Europejską, która nastąpiła l maja 2004 r., spowodowała wpływ regulacji prawnych Unii na problematykę ochrony pracy. Organy wspólnot ze

22 Dz. U. z 1977 r., Nr 38, poz. 169.

${ }_{23}$ Zob. E. Kołodziejczyk, Podstawy prawne bezpieczeństwa i higieny pracy, w: Bezpieczeństwo i higiena pracy, K. Grabowska-Wawrzenicka (red.), Warszawa 2010, s. 16; D. Koradecka, Prawna ochrona pracy, w: Bezpieczeństwo i higiena pracy, D. Koradecka (red.), Warszawa 2008, s. 41 i n.

${ }^{24}$ Treść traktatu zamieszczona została w opracowaniu Dokumenty Europejskie, t. I, Lublin 1996, s. 106; zob. też T. Wyka, Ochrona zdrowia i życia pracowników jako element trési stosunku pracy, Warszawa 2003, s. 82-83. 
wszystkich zakresów prawa pracy najwięcej uwagi poświęciły problematyce ochrony pracy, wydając ponad 100 dyrektyw, które wyłącznie bądź pośrednio regulują tę problematykę $e^{25}$.

Zarówno w prawie Unii Europejskiej, jak i prawie polskim nie ma jednakże jednolitej terminologii w zakresie ochrony pracy i ujęcia tej ochrony. W literaturze angielskiej częściej używane jest określenie „bezpieczeństwo i ochrona zdrowia”, a w literaturze niemieckiej używa się terminu „ochrona zdrowia”. W prawie polskim najczęściej używa się natomiast określenia „bezpieczeństwo i higiena pracy”. Nie ulega jednak wątpliwości, że zdrowie decyduje o wartości życia człowieka i jest wskazywane oprócz życia jako wartość podlegająca szczególnej ochronie prawnej, stanowiąc dla człowieka najwyższą wartość. Dopóki też zdrowie rozpatrywane było głównie w kategoriach humanitarnych, dopóty stanowiło wartość zwłaszcza jednostki. Obecnie jednak coraz częściej ujmuje się je w kategoriach ekonomicznych i ogólnospołecznych, co nie powinno zmniejszać o nie troski zarówno państwa, jak i podmiotów zatrudniających. Choroby i wypadki powodują bowiem straty społeczne i ekonomiczne nie tylko wobec poszczególnych osób, których dotyczą bezpośrednio, ale i dla państwa, wpływając równocześnie na ocenę sprawujących władzę ${ }^{26}$.

Zagrożenia zdrowia i życia mogą pochodzić z różnych źródeł, w tym także z naruszeń przepisów bezpieczeństwa i higieny pracy warunkujących bezpieczne warunki pracy. Działania zmierzające do zapewnienia ochrony zdrowia i życia są też przedmiotem regulacji różnych aktów normatywnych, w tym także przepisów ustawodawstwa pracy.

Najważniejszym aktem prawnym z tego zakresu w państwach Wspólnoty jest Dyrektywa 89/391/EEC dotycząca realizacji przedsięwzięć mających na celu poprawę bezpieczeństwa i ochrony zdrowia pracowników podczas pracy. Reguluje ona w sposób najbardziej ogólny sprawy ochrony życia i zdrowia pracowników, stąd też nazywana jest „dyrektywą ramową”. Przedmiotowa dyrektywa uchwalona została przez Radę 12 czerwca 1989 r. i wskazana przez instytucje unijne jako podstawa prawna europejskiego systemu prawa bezpieczeństwa i higieny pracy ze względu na nowe podejście do zagadnień ochrony pracy. To nowe podejście Dyrektywy 89/391/EEC do zagadnień ochrony pracy wyraża się w elastycznym sposobie regulacji oraz metodach stosowanych w celu zapobiegania zagrożeniom ${ }^{27}$.

25 L. Florek, Europejskie prawo pracy, Warszawa 2010, s. 207.

26 Zdrowie jest to stan żywego organizmu, w którym wszystkie funkcje przebiegają prawidłowo. Pełna sprawność i dobre samopoczucie - Uniwersalny słownik języka polskiego, S. Dubisz (red.), Warszawa 2003, t. 4, s. 952. Zdrowie to też stan pełnej sprawności fizycznej, psychicznej i społecznej - w węższym znaczeniu nieobecność choroby lub kalectwa. Z fizjologicznego punktu widzenia zdrowie jest to pełna zdolność organizmu do utrzymywania równowagi między nim a środowiskiem zewnętrznym w zakresie prawidłowego reagowania na zmiany środowiska i adaptacji do tych zmian. Nauką zajmującą się zdrowiem jest higiena, a utrzymaniem i przywracaniem zdrowia - medycyna, Nowa encyklopedia powszechna PWN, praca zbiorowa, B. Petrozolin-Skowrońska (red.), t. IV, Warszawa 1996. Zdrowie zostało też zdefiniowane przez Światową Organizację Zdrowia jako stan pełnego dobrostanu fizycznego, psychicznego i społecznego; zob. też D. Koradecka, Naukowe podstawy ochrony pracy w standardach europejskich. Materiały z konferencji „Wspólna Europa - wspólne zasady i priorytety Inspekcji Pracy”, Wrocław 2004, s. 12.

27 A.M. Świątkowski, Bezpieczeństwo i higiena pracy. Komentarz. Kraków 2003, s. 169-170. 
Z zakresu przedmiotowego tej dyrektywy wynika, że ma ona powszechne zastosowanie. Dotyczy bowiem wszystkich sektorów działalności publicznej i prywatnej. Zasada powszechnego stosowania dyrektywy znajduje potwierdzenie w przepisie art. 2 ust. 2, w którym wymienione zostały szczególne sektory, takie jak np. siły zbrojne, policja, służba ochrony cywilnej, w których ze względu na specyficzny charakter działalności publicznej nie można stosować dyrektywy. Zawiera ona bowiem postanowienia sprzeczne z wymienionymi rodzajami specyficznej działalności publicznej. Jednakże w razie oczywistej kolizji postanowień dyrektywy ramowej ze szczegółowymi rodzajami działalności publicznej wymienionej w art. 2 ust. 2, zd. 2 tej dyrektywy, nakłada ona na instytucje publiczne obowiązek zapewnienia maksimum bezpieczeństwa i ochrony zdrowia pracownikom (funkcjonariuszom) zatrudnionym w służbie publicznej w myśl wytycznych w niej zamieszczonych ${ }^{28}$.

Wskazując na regulacje dotyczące bezpieczeństwa i ochrony zdrowia pracowników w prawie Unii, należy także zauważyć regulacje, które dotyczą ochrony przed specyficznymi zagrożeniami. Podstawy prawne ochrony w tym zakresie stanowią również inne dyrektywy, jak np. dyrektywa 80/1107/EWG znowelizowana dyrektywą 88/642 i uzupełniona wieloma dyrektywami szczegółowymi określającymi zasady ochrony przed działaniem różnorodnych czynników szkodliwych ${ }^{29}$.

Bardzo zbliżone, a niekiedy wręcz tożsame są też różne obowiązki w zakresie bezpieczeństwa i higieny pracy wobec osób zatrudnionych w służbach mundurowych na podstawie administracyjnoprawnego stosunku służbowego, np. w zakresie szkoleń, badań lekarskich, oceny ryzyka zawodowego, zarządzania bezpieczeństwem i ochroną zdrowia. Ewentualne różnice wobec zatrudniania na podstawie stosunku pracy polegają na formie i zakresie realizacji warunkowanej specyfiką poszczególnych służb mundurowych, czy też wykonywaniu określonych prac np. szczególnie niebezpiecznych. Należy przy tym zauważyć, że w niektórych służbach mundurowych zatrudnieni są na podstawie umów o pracę także pracownicy cywilni wykonujący różnego rodzaju czynności administracyjne i pomocnicze, wobec których w zakresie bhp i zawartego z nimi stosunku pracy mają zastosowanie określone przepisy prawa pracy, np. ustawa o służbie cywilnej, ustawa o pracownikach urzędów państwowych oraz określone przepisy Kodeksu pracy.

Ze stanem bezpieczeństwa i higieny pracy oraz służby związane są bardzo ważne skutki społeczne i ekonomiczne. Stan ten ma też głęboki aspekt humanistyczny, ogólnoludzki, stąd też zapewnienie bezpiecznych i higienicznych warunków pracy i służby bez względu na podstawę nawiązania określonego stosunku prawnego, to nie tylko zadanie państwa oraz podmiotów zatrudniających, lecz także nakazy

28 Tamże, s. 169-170.

29 Szerzej na temat dyrektyw szczegółowych w odniesieniu do dyrektywy ramowej 80/1107/EWG: T. Wyka, Ochrona zdrowia pracowników w świetle dyrektywy EWG $i$ ustawodawstwa polskiego, w: Biała ksiega Polska-Unia Europejska, Nr 22, Ochrona zdrowia i życia obywateli, Warszawa 1995, s. 70 i n. 
moralne, które powinny być przedmiotem szczególnej uwagi wszystkich organów i osób, które w jakimkolwiek charakterze mają wpływ na to bezpieczeństwo.

\section{Problematyka ryzyka jako przedmiot zainteresowania wielu dyscyplin naukowych}

Problematyka ryzyka nie jest wyłączną domeną prawa administracyjnego. Jest ona bowiem przedmiotem zainteresowania wielu dyscyplin naukowych i oddziaływania różnych gałęzi prawa, które niekiedy wzajemnie się przenikają.

Ryzyko kojarzone jest zazwyczaj z niebezpieczeństwem i zagrożeniem różnych wartości chronionych. Dookreślane jest ono często przymiotnikiem. W prawie pracy występuje jako ryzyko zawodowe. Nie ma bowiem stanowiska pracy, na którym ono nie miało miejsca.

Występowanie ryzyka zawodowego nie jest też wyłącznie związane z zatrudnieniem na podstawie stosunku pracy. Występuje ono również w stosunku służbowym nawiązywanym na podstawie przepisów prawa administracyjnego $\mathrm{w}$ wielu podmiotach publicznych, np. w służbach mundurowych. Ustawy ustrojowe dotyczące tych służb korzystają w przedmiocie ryzyka zawodowego z rozwiązań prawa pracy, odsyłając do tego prawa, a w szczególności Ustawy z dnia 26 czerwca 1974 r. Kodeks pracy ${ }^{30}$, normującej obowiązki w zakresie bezpieczeństwa i higieny pracy. Jest to też przykład przenikania prawa pracy do prawa administracyjnego. Także i prawo administracyjne, jak już zauważono w wielu rozwiązaniach, przenika do prawa pracy, np. poprzez państwowe ograny nadzoru i kontroli.

Prawodawca w $\$ 2$ pkt. 7 Rozporządzenia Ministra Pracy i Polityki Społecznej z dnia 26 września 1997 r. w sprawie ogólnych przepisów bezpieczeństwa i higieny pracy ${ }^{31}$ określił ryzyko zawodowe jako prawdopodobieństwo wystąpienia niepożądanych zdarzeń związanych z wykonywaną pracą powodujących straty, w szczególności występowanie u pracowników niekorzystnych skutków zdrowotnych w wyniku zagrożeń zawodowych występujących w środowisku pracy lub sposobu wykonywania pracy. Szczególnie pierwsza część tego określenia wskazująca na prawdopodobieństwo występowania niekorzystnych zdarzeń jest również właściwa dla określenia ryzyka w innych dyscyplinach naukowych i gałęziach prawa.

Także Komisja Europejska w wytycznych dotyczących oceny ryzyka zawodowego zawarła ocenę tego ryzyka, stwierdzając, że stanowi ono w konsekwencji prawdopodobieństwo potencjalnej możliwości powstania urazu lub pogorszenia stanu zdrowia wskutek narażenia na oddziaływanie czynnika zagrażającego ${ }^{32}$.

30 Tekst jednolity Dz. U. z 2016 r., poz. 1666 ze zm.

31 Tekst jednolity Dz. U. z 2003 r., Nr 169, poz. 1650 ze zm.

32 Zob. W.L. Krupa, Zarzadzanie ochrona pracy, w: Bezpieczeństwo i higiena pracy, K. Grabowska-Wawrzenicka (red.), Warszawa 2010, s. 443-444. 
Unia Europejska też i w powołanej już Dyrektywie 89/391/EEC, zwanej Ramową, uchwalonej przez Radę 12 czerwca 1989 r., wskazała na znaczenie oceny ryzyka zawodowego i informowania o nim pracowników ${ }^{33}$.

Wymagania dotyczące przeprowadzania ryzyka zawodowego zawarte są w Ustawie z dnia 26 czerwca 1974 r. Kodeks pracy i powołanym rozporządzeniu Ministra Pracy i Polityki Społecznej w sprawie ogólnych przepisów bezpieczeństwa i higieny pracy, a także w wielu innych przepisach $\mathrm{z}$ zakresu prawa pracy.

W 2002 r. uchwałą Polskiego Komitetu Normalizacyjnego Nr 1/2000 wprowadzona została Polska Norma PN-N-18002 Systemy Zarządzania Bezpieczeństwem i Higieną Pracy, zawierająca ogólne wytyczne do oceny ryzyka zawodowego i wskazania dotyczące postępowania przy przeprowadzaniu oceny tego ryzyka na stanowiskach pracy, w tym ogólne zasady przygotowania oceny ryzyka. Na podstawie tej normy Centralny Instytut Ochrony Pracy - Państwowy Instytut Badawczy opracował program komputerowy dotyczący oceny tego ryzyka pod nazwą STER. Powołane wytyczne i program wskazują na traktowanie tej oceny jako procesu wieloetapowego ${ }^{34}$.

Kolejne różnie ujmowane etapy oceny ryzyka zawodowego obejmują np.:

- zebranie informacji w celu identyfikacji zagrożeń;

- oszacowanie ryzyka, czyli określenie prawdopodobieństwa występowania i ciężkości potencjalnych skutków zagrożeń dla zdrowia i życia;

- wyznaczanie dopuszczalności ryzyka zawodowego bądź konieczności podjęcia działań niezbędnych do jego ograniczenia lub wyeliminowania.

Niezbędnym bezpośrednim następstwem oceny ryzyka zawodowego jest zawsze weryfikacja dotychczasowych środków pod kątem ich efektywności i działań eliminujących bądź też ograniczających ryzyko, które to działania powinny być podmiotem stałej obserwacji ${ }^{35}$.

Poprawna i efektywna ocena ryzyka bez względu na to, czego dotyczy, wymaga zawsze zapewnienia niezbędnych zasobów i wyznaczenia osób odpowiedzialnych za jej przeprowadzanie, umożliwienia dostępu do przedmiotu oceny i wskazania sposobu informacji o ryzyku. Ocena ryzyka jest bowiem w każdym przypadku następstwem racjonalnego postępowania, które przejawia się w badaniu zagrożeń i zdarzeń niebezpiecznych ze szczególną starannością. Proces zaś obejmujący ocenę ryzyka, eliminowanie bądź zmniejszanie zagrożeń, zawierający w sobie działania naprawcze podmiotu zobowiązanego do jego prowadzenia, określany jest jako zarządzanie ryzykiem ${ }^{36}$.

Istnieje wiele metod badania zagrożeń i szacowania ryzyka, które nie są wyłącznie właściwe ustawodawstwu pracy, określanych jako metody indukcyjne i dedukcyjne.

33 Zob. A.M. Świątkowski, Bezpieczeństwo i higiena pracy..., s. 169-170; OIL 183/1. Polski przekład: Dyrektywy EWG CIOP, Warszawa 2001, t. I, s. 9 i n.

34 Zob. W.L. Krupa, Zarządzanie ochrona pracy, s. 434.

35 Z. Pawłowska, Podstawowe kierunki kształtowania warunków pracy i ergonomii, w: Bezpieczeństwo i higiena pracy, D. Koradecka (red.), Warszawa 2008, s. 577 i n.; M. Gołusza (red.), Poradnik stużby bhp, Kraków-Tarnobrzeg 2014, s. 505 i n.

36 Tamże, s. 512. 
W indukcyjnych wnioski ogólne wyprowadzane są z przesłanek, które są ich szczególnymi przypadkami, a w metodach dedukcyjnych analiza prowadzona jest zgodnie z kierunkiem następstw logicznych. Ze względu na precyzję, z jaką występuje ocena ryzyka, rozróżnia się także metody jakościowe i ilościowe, które są uzależnione od dostępu do danych pozwalających na wiarygodne oszacowanie ryzyka.

W metodach oceny ryzyka wyróżnia się także różną metodologię, której wspólne cechy pozwalają na wyróżnienie jeszcze takich metod, jak matrycowe, wskaźnikowe, grafy i inne.

\section{Podsumowanie i wnioski}

Zgodnie z art. 226 Ustawy z dnia 26 czerwca 1974 r. Kodeks pracy do zasadniczych obowiązków pracodawcy należy dokonywanie i dokumentowanie ryzyka zawodowego związanego z wykonywaną pracą oraz stosowanie niezbędnych środków zmniejszających ryzyko, a także informowanie pracowników o tym ryzyku i zasadach ochrony przed zagrożeniami. Obowiązki w tym przedmiocie dotyczą także nawiązywania zatrudnienia na podstawie stosunku administracyjno-prawnego.

Nie ulega wątpliwości, że na rozmiar ryzyka zawodowego ma zasadniczy wpływ przestrzeganie przepisów i zasad bezpieczeństwa pracy (służby) przez wszystkie podmioty zobowiązane (pracodawców, osoby pełniące funkcje kierownicze i kierujące określonymi służbami, a także i pracowników czy wykonujących służbę). Główny obowiązek w zakresie zapobiegania występowaniu ryzyka w określonych rozmiarach przypada jednak pracodawcom i podmiotom nawiązującym stosunki służbowe.

Podstaw prawnych tego obowiązku, jak już zauważono, należy w szczególności upatrywać $\mathrm{w}$ art. 66 Konstytucji RP z dnia 2 kwietnia 1997 r. ${ }^{37}$ podkreślającym prawo każdego do bezpiecznych i higienicznych warunków pracy i w art. 24 wskazującym na ochronę pracy przez Rzeczpospolitą Polską oraz sprawowanie nadzoru nad warunkami wykonywania pracy przez państwo. Rozwinięcie tych zasad następuje w przepisach prawa pracy i prawa administracyjnego, które dotyczą nawiązywania stosunków służbowych.

Biorąc pod uwagę regulacje międzynarodowe, należy zwrócić uwagę na wskazane już prawa człowieka służące jednostce w świetle prawa międzynarodowego i wewnątrzkrajowego. Prawa te stały się jedną z najważniejszych idei i instytucji współczesnego świata. Także organy Unii Europejskiej poświęciły problematyce ochrony pracy ponad 100 dyrektyw, które wyłącznie lub pośrednio ją regulują ${ }^{38}$.

37 Dz. U., Nr 78, poz. 483 ze zm.

38 Zob. K. Motyka, Prawa człowieka. Wprowadzenie, wybór źródeł, Lublin 2004, s. 15 i n.; I. Hołda, Z. Hołda, D. Ostrowska, J.A. Rybczyńska, Prawa człowieka. Zarys wykładu, Warszawa 2011, s. 11, 28, 73, 84 i n.; T. Wyka, Prawa człowieka a prawa pracownicze wg Jana Pawła II, w: Prawa człowieka. Współczesne zjawiska, wyzwania, zagrożenia, A. Kalisz (red.), Sosnowiec 2015, s. 163 i n. 
Jednym z egzekutorów obowiązków związanych z zatrudnieniem na podstawie stosunku pracy jest Państwowa Inspekcja Pracy jako główny podmiot publiczny w zakresie nadzoru i kontroli nad przestrzeganiem prawa pracy i innych ustaw ${ }^{39}$. Kontroli Państwowej Inspekcji Pracy w tym przedmiocie nie podlegają jednak podmioty publiczne, w których następuje nawiązanie stosunku służbowego na podstawie administracyjnoprawnej, co jest zjawiskiem bardzo niekorzystnym dla praworządności związanej z tym rodzajem zatrudnienia ${ }^{40}$. Nawet Ustawa z dnia 15 lipca 2011 r. o kontroli administracji rządowej ${ }^{41}$, określając zasady i tryb przeprowadzania kontroli działalności organów administracji rządowej i innych jednostek kontrolowanych przez organy właściwe w sprawach kontroli, pomija problematykę oceny ryzyka zawodowego w swojej treści, która to ocena rzutuje w konsekwencji w sposób szczególnie istotny na realizację działania zadań i efektywność administracji.

Państwowa Inspekcja Pracy działająca na podstawie Ustawy z dnia 13 kwietnia $2007 \mathrm{roku}^{42}$ o tej inspekcji ma możliwości obligowania pracodawców decyzjami administracyjnymi jako aktami nadzoru wydawanymi na podstawie art. 17 ustawy do m.in. usunięcia stwierdzonych uchybień w ustalonym terminie, które wiążą się z realizacją obowiązków określonych w art. 226 Kodeksu pracy związanych z oceną i dokumentowaniem ryzyka zawodowego oraz zastosowaniem niezbędnych środków profilaktycznych zmniejszających ryzyko, w tym wykonaniem obowiązku informacyjnego wobec pracowników o ryzyku i zasadach ochrony przed zagrożeniami. Innym środkiem prawnym przymuszającym do praworządnych zachowań w procesie pracy jest odpowiedzialność za wykroczenie przeciwko prawom pracownika przewidziane w dziale XIII Kodeksu pracy. Zgodnie z art. 283 tego kodeksu nieprzestrzeganie przepisów i zasad bezpieczeństwa i higieny pracy przez wskazanego w tym przepisie adresata obowiązków zagrożone jest karą grzywny od $1000 \mathrm{zł}$ do $30000 \mathrm{zł}$.

Stan przestrzegania obowiązków wobec świadczących pracę i służbę nie jest w pełni zadowalający. Wskazują na to różnego rodzaju sprawozdania, informacje przekazywane przez środki przekazu czy też akcje protestacyjne ${ }^{43}$.

Brak wyspecjalizowanego organu nadzoru w służbach mundurowych skłania do refleksji, czy taki stan jest poprawny. Czy doraźnie nie należałoby zwiększyć co najmniej oddziaływania kontrolne w możliwych obecnie formach dla ustalenia stanów niezgodnych z prawem w celu ich usuwania poprzez środki prawne właściwe dla kontroli? Państwowa Inspekcja Pracy

39 Zob. M. Liwo, Egzekwowanie obowiązów od podmiotów nawiązujących stosunki pracy i stosunki służbowe w postępowaniu administracyjnym, Przegląd Prawa Publicznego 2016, 1, s. 41 i n.

40 Zob. Tenże, Status stużb mundurowych i funkcjonariuszy w nich zatrudnionych, Warszawa 2011, s. 329 i $n$.

41 Dz. U. z 2011 r., Nr 185, poz. 1092.

42 Tekst jednolity, Dz. U. z 2018 r., poz. 623.

43 Zob. m.in. Sprawozdanie Głównego Inspektora Pracy z działalności Państwowej Inspekcji Pracy za rok 2016 i 2017; M. Liwo, Safety and health at work, the governmental services as a determinant of social safety, w: Occupational Health and Safety at Workplaces, A. Pacana, G. Ostasz (red. nauk.), Rzeszów 2018, s. 49 i n. 
w ramach swojej właściwości nieobejmującej jednakże stosunków służbowych powinna natomiast rozwinąć zakres działań, które należy podjąć, przy niezadowalającej skuteczności działań dotychczasowych. To też jest problem nie tylko samej inspekcji, lecz także innych organów państwowych, którym nie powinien być obojętny stan warunków pracy w Polsce, od wielu lat nieulegający oczekiwanej poprawie.

Poprawne ustalenie ryzyka bez względu na jego nazwę ma bowiem zasadnicze znaczenie dla efektywnego zarządzania w różnych dziedzinach działalności człowieka, np. w administracji, prawie pracy, gospodarce, służbie zdrowia itp. Należy zatem przyjąć, że ryzyko jest jednym z zasadniczych determinantów tego zarządzania, ponieważ bez jego ustalenia zarządzanie nie jest możliwe.

Ryzyko bez względu na to, czego dotyczy, nie jest - podobnie jak bezpieczeństwo i niebezpieczeństwo, z którym jest związane - zjawiskiem trwałym. Ulega bowiem systematycznym zmianom w zależności od wielu uwarunkowań. Stąd też potrzeba jego systematycznego monitorowania, ocen oraz wdrażania wniosków, które z tych ocen wynikają. $Z$ tytułu powiązania z określonymi stosunkami prawnymi wymaga ono również racjonalnych unormowań prawnych i szeroko rozumianej świadomości prawnej adresatów tych unormowań. Jest to szczególnie ważne w różnych formach współczesnego administrowania zarówno w działalności podmiotów publicznych, jak i prywatnych ${ }^{44}$.

\section{Bibliografia}

Celeda R., Zasady bezpieczeństwa i higieny pracy, Informator Ochrony Pracy 2009, 1.

Cieślak Z., Normy techniczne, w: Prawo administracyjne, Z. Niewiadomski (red.), Warszawa 2007.

Flasiński M., Bezpieczeństwo pracy. Prawne formy zapobiegania zagrożeniom, Warszawa 1989.

Florek L., Europejskie prawo pracy, Warszawa 2010.

Florek L., Prawna ochrona pracowników. Studia i materiaty, Warszawa 1990.

Florek L., Zieliński T., Prawo pracy a polityka społeczno-gospodarcza i postęp społeczny, w: Z problematyki prawa pracy i polityki socjalnej, T. Zieliński (red.), t. I, Katowice 1977.

Gdulewicz E., Konstytucyjny system źródeł prawa, w: Polskie prawo konstytucyjne, W. Skrzydło (red.), Lublin 2011.

Gdulewicz E., Konstytucyjny system źródeł prawa, w: Polska lat dziewięćdziesiątych. Przemiany państwa i prawa, t. II, L. Antonowicz, H. Groszyk, M. Sawczuk, W. Skrzydło, T. Bojarski (red.), Lublin 1998.

Gersdorf M., Stosunek pracy, w: Kodeks pracy. Komentarz, Z. Selwa (red.), Warszawa 2008.

Gołusza M. (red.), Poradnik służby bhp, Kraków-Tarnobrzeg 2014.

Hołda I., Hołda Z., Ostrowska D., Rybczyńska J.A., Prawa człowieka. Zarys wykładu, Warszawa 2011.

Jaśkiewicz W., Jackowiak Cz., Piotrowski W., Prawo pracy w zarysie, Warszawa 1985.

${ }_{44}$ Zob. M. Liwo, Egzekwowanie obowiązków od podmiotów nawiązujących stosunki pracy i stosunki stużbowe..., s. 41 i n. 
Jedliński A., Kaczyński L., Statut jako źródło prawa pracy, Państwowa Inspekcja Pracy 1999, 4. Kołodziejczyk E., Podstawy prawne bezpieczeństwa i higieny pracy, w: Bezpieczeństwo i higiena pracy, K. Grabowska-Wawrzenicka (red.), Warszawa 2010.

Koradecka D., Naukowe podstawy ochrony pracy w standardach europejskich. Materiały z konferencji „Wspólna Europa - wspólne zasady i priorytety Inspekcji Pracy”, Wrocław 2004.

Koradecka D., Prawna ochrona pracy, w: Bezpieczeństwo i higiena pracy, D. Koradecka (red.), Warszawa 2008.

Krupa W.L., Zarzadzanie ochrona pracy, w: Bezpieczeństwo i higiena pracy, K. Grabowska-Wawrzenicka (red.), Warszawa 2010.

Leoński Z., Działania administracji publicznej w stanach zagrożenia - policja administracyjna, w: Materialne prawo administracyjne, Z. Leoński (red.), Warszawa 2006.

Liwo M., Egzekwowanie obowiązków od podmiotów nawiązujących stosunki pracy i stosunki służbowe w postępowaniu administracyjnym, Przegląd Prawa Publicznego 2016, 1.

Liwo M., Ochrona pracy w Konstytucji RP z 2.04.1997 r., w prawie międzynarodowym oraz prawie Unii Europejskiej, w: Środki ochrony praw słusznie nabytych $w$ Konstytucji RP i prawie Unii Europejskiej, H. Zięba-Załucka, P. Chmielnicki (red.), Warszawa 2012.

Liwo M., Safety and health at work, the governmental services as a determinant of social safety, w: Occupational Health and Safety at Workplaces, A. Pacana, G. Ostasz (red. nauk.), Rzeszów 2018.

Liwo M., Służba publiczna a prawa człowieka, w: Prawa człowieka. Współczesne zjawiska, wyzwania, zagrożenia, A. Kalisz (red.), Sosnowiec 2015.

Liwo M., Status służb mundurowych i funkcjonariuszy w nich zatrudnionych, Warszawa 2011.

Liwo M., Wolińska A., Ochrona pracy i system jej realizacji, Miesięcznik Ochrony Pracy „Atest” 2008, 2.

Modliński E., Bezpieczeństwo i higiena pracy, Warszawa 1975.

Motyka K., Prawa człowieka. Wprowadzenie, wybór źródeł, Lublin 2004.

Muszalski W., Prawo bezpieczeństwa i higieny pracy oraz jego stosowanie, w: Z problematyki prawa pracy i polityki socjalnej, T. Zieliński (red.), t. II, Katowice 1979.

Nowa encyklopedia powszechna PWN, praca zbiorowa, B. Petrozolin-Skowrońska (red.), t. IV, Warszawa 1996.

Nycz T.M., Kodeks pracy z komentarzem, Kraków-Tarnobrzeg 2008.

Nycz T., Konstytucyjne gwarancje bezpiecznych i higienicznych warunków pracy, Tarnobrzeg 2000.

OIL 183/1. Polski przekład: Dyrektywy EWG CIOP, Warszawa 2001, t. I.

Pacholski L., Założenia systemu ochrony pracy w Polsce, w: Ochrona pracy a przemiany społeczno-ekonomiczne w Polsce, R. Szpor (red.), Warszawa 1994.

Pawłowska Z., Podstawowe kierunki kształtowania warunków pracy i ergonomii, w: Bezpieczeństwo i higiena pracy, D. Koradecka (red.), Warszawa 2008.

Pawłowska Z., Ocena ryzyka zawodowego, w: Bezpieczeństwo i higiena pracy, D. Koradecka (red.), Warszawa 2008.

Peyrefitte A., Wymiar sprawiedliwości. Między ideałem a rzeczywistością, tłum. J.M. Padlewska, B. Hołysta (red.), Warszawa 1987.

Skoczyński J., Regulaminy pracy, w: Źródła prawa pracy, L. Florek (red.), Warszawa 2000. 
Sprawozdanie Głównego Inspektora Pracy z działalności Państwowej Inspekcji Pracy za rok 2016 i 2017.

Stanowisko Stowarzyszenia Ochrony Pracy w sprawie pojęcia przepisów bhp w prawie pracy, Informator Ochrony Pracy 2010, VII-IX.

Szubert W., Ochrona pracy, Warszawa 1966.

Szubert W., Szczególne właściwości prawa pracy, t. IV, Łódź 1970.

Szubert W., Uwagi o pojęciu ochrony pracy, w: Rozprawy prawnicze. Ksiega pamiątkowa dla uczczenia pracy naukowej K. Przybyłowskiego, praca zbiorowa, Kraków-Warszawa 1964.

Szymański K.R., Majdan T., Leksykon ochrony pracy, Warszawa 2007 (tytuł oryginalny: Taschen Lexikon Arbeit und Gasundheit Wisbaden).

Świątkowski A.M., Bezpieczeństwo i higiena pracy. Komentarz, Kraków 2003.

Uniwersalny słownik języka polskiego, S. Dubisz (red.), Warszawa 2003, t. 4.

Ura E., Prawo administracyjne, Warszawa 2008.

Wyka T., Ochrona zdrowia i życia pracowników jako element treści stosunku pracy, Warszawa 2003.

Wyka T., Ochrona zdrowia pracowników w świetle dyrektywy EWG i ustawodawstwa polskiego, w: Biała ksiegga Polska-Unia Europejska, Nr 22, Ochrona zdrowia i życia obywateli, Warszawa 1995.

Zakrzewski W., Podstawowe prawa i obowiązki człowieka i obywatela, w: Polskie prawo konstytucyjne, W. Skrzydło (red.), Lublin 2011.

Wyka T., Prawa człowieka a prawa pracownicze wg Jana Pawła II, w: Prawa człowieka. Współczesne zjawiska, wyzwania, zagrożenia, A. Kalisz (red.), Sosnowiec 2015.

Zakrzewski Z., Konstytucyjne zasady ustroju, w: Polskie prawo konstytucyjne, W. Skrzydło (red.), Lublin 2011.

Zieliński T., Stosunek prawa pracy do prawa administracyjnego, Warszawa 1977.

Zieliński T., Zarys wykładu prawa pracy, cz. III, Katowice 1984. 